\title{
Margaret McCartney: An economist explains why healthcare can't be treated as a market
}

\author{
Margaret McCartney general practitioner
}

Glasgow

Kenneth Arrow died in February 2017 in California, aged 95. The most important economist you've probably never heard of, he was the youngest economist to win a Nobel prize and is widely lauded as "one of the most brilliant economic minds of the 20th century."

Searching for traces of how healthcare has been organised-or not-in the UK, I read his seminal 1963 paper, Uncertainty and the Welfare Economics of Medical Care. ${ }^{2}$ In it he wrote, "The special economic problems of medical care can be explained as adaptations to the existence of uncertainty in the incidence of disease and the efficacy of treatment."

It's a beautifully written piece, such that a non-economist can appreciate it. I asked whether I could interview him by phone and email for The State of Medicine, a book I was writing. He was a delight. His slow, dignified American drawl was full of considered, urbane insight.

A competitive healthcare market is grounded in the expectation that some hospitals or surgeries will go bust

He still held the view that medical care can't be delivered through a market approach in the same way as other goods and services. Doctors are meant to offer care "dictated by the objective needs of the case and not limited by financial considerations." But information held by insurers, doctors, and patients is always unequal. And, crucially, it's expected that doctors' concern "for the correct conveying of information will, when appropriate, outweigh their desire to please their customers."

I asked him whether this would change as medical information becomes more widely available. What about the internet revolution? What about "rate my hospital" and "rate my doctor" websites? Don't they create the information equilibrium needed to make healthcare marketable?

He laughed down the phone.
They pose some big problems, he explained: "In practice, the theoretical advantages of choice are outweighed by the fact that people don't do a good job of making these choices in a competitive environment-it's almost impossible."

Competitive markets mean that information becomes commercial: we're advertised to, not advised. A competitive healthcare market is grounded in the expectation that some hospitals or surgeries will go bust. Instability is normal, so hospitals or GP surgeries will fold in the normal course of events. Such markets work well for groceries: if a supermarket closes you can get your carrots elsewhere. But healthcare isn't a comparable transaction, he argued. Changes in professionals are "deleterious to an ongoing relationship."

Arrow was an economist who knew that human care was not readily appreciated on spreadsheets. I told him about the uncontrolled ideological experiment in the UK-how NHS England had decided to marketise healthcare and how the devolved nations had disagreed. I told him about the resources sacrificed to create a market that wasn't needed.

He was perturbed: "We looked to the NHS to see how it should be done."

"There's always Scotland," I said.

Competing interests: See www.bmj.com/about-bmj/freelancecontributors/margaret-mccartney.

Provenance and peer review: Commissioned; not externally peer reviewed.

Follow Margaret on Twitter, @mgtmccartney

1 Weinstein MM. Kenneth Arrow, Nobel-winning economist whose influence spanned decades, dies at 95. New York Times 21 Feb 2017. https://www.nytimes.com/2017/02 21/business/economy/kenneth-arrow-dead-nobel-laureate-in-economics.html. 2 Arrow KJ. Uncertainty and the welfare economics of medical care. Am Econ Rev 1963;358:941-73.

Published by the BMJ Publishing Group Limited. For permission to use (where not already granted under a licence) please go to http://group.bmj.com/group/rights-licensing/ permissions 